\begin{tabular}{|c|c|}
\hline JURNAL ABDIMAS & P-ISSN 2615-6849, E-ISSN 2716-070X \\
\hline 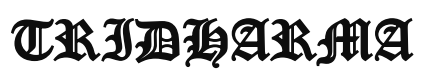 & Jurnal ABDIMAS Vol. 1,No.2, Mei 2020,Hal(25-32) \\
\hline AtA & $\begin{array}{l}\text { @Prod1 Manajemen Fakultas EKonomi Universitas Pamulang } \\
\text { Email: abdimasjurnal.unpam@ gmail.com Telp: (021) 741-2566 }\end{array}$ \\
\hline
\end{tabular}

\title{
PENGELOLAAN KEUANGAN KELUARGA PADA KELOMPOK PENGAJIAN IBU-IBU SEKELURAHAN PAMULANG BARAT TANGERANG SELATAN
}

\author{
Bulan Oktrima, Muliahadi Tumanngor, Waluyo Jati, Tri Wartono, \\ Ade Ratna Sari \\ Dosen Ekonomi Fakultas Ekonomi Universitas Pamulang \\ Emaildosen00790@unpam.ac.id , dosen00871@unpam.ac.id , \\ dosen00565@unpam.ac.id, dosen00126@unpam.ac.id, dosen00819@unpam.ac.id
}

\begin{abstract}
ABSTRAK
Pengabdian ini berjudulPengelolaan Keuangan Keluarga Pada Kelompok Pengajian Ibu-Ibu Sekelurahan Pamulang Barat, Tangerang Selatan.

Tujuan pengabdian ini adalah untukMembantu memberikan arahan mengenai Manajemen Keuangan, Pengelolaan keuangan keluarga, dan apa yang harus dilakukan oleh pada Kelompok Pengajian Ibu-Ibu Sekelurahan Pamulang Barat.

Metode pelaksanaan pengabdian ini dilakukan dalam beberapa kegiatan yaitu tahap survei yaitu sosialisasi dilakukan dengan menyusun berbagai hal yang akan disampaikan pada saat kegiatan pengabdian yang akan dilakukan yang meliputi: penyusunan materi yang akan diberikan, penyusunan jadwal pemberian materi, pembagian tugas tim pengabdian dan survei ke lokasi pengabdian. Tahap sosialisasi yaitu sebelum kegiatan pengabdian dilaksanakan terlebih dahulu dilakukan tahap sosialisasi yaitu melakukan silaturahmi dengan ketua yayasan, menyampaikan maksud dan tujuan pengabdian ini. Pada tahap ini juga dilakukan jalinan kerjasama dan menentukan jadwal kegiatan pengabdian. Tim pelaksana kegiatan pengabdian pada masyarakat adalah dosen Fakultas Ekonomi jurusan manajemen sebanyak 5 orang. Tim pengabdian memberikan materi tentang manajemen keuangan dan pengelolaan keuangan.

Kesimpulan dari pengabdian ini adalah Peserta diberikan materi mengenai Pengelolaan keuangan dimana sifatnya administratif yang berkaitan dengan kegiatan perencanaan anggaran, penyimpanan, penggunaan, pencatatan dan pengawasan keluar masuknya uang/dana, kelompok Ibu-ibu pengajian sekelurahan Pamulang Barat.
\end{abstract}

\section{Kata Kunci: Keuangan Keluarga, Penghasilan Keluarga, dan Pengeluaran Keluarga \\ ABSTRACT \\ This dedication is entitled Family Financial Management in the Study Group of Women in the District of Pamulang Barat, South Tangerang.The purpose of this dedication is to help provide direction on financial management, family financial management, and what must be done by the Pamulang Barat Village Study Group for Women.}

The method of implementing this service is carried out in several activities, namely the survey stage, namely the socialization carried out by arranging various things to be delivered at the time of service activities that will be carried out which include: preparation of material to be given, preparation of material delivery schedule, division of tasks of the service team and survey to the location devotion. The socialization phase is 


\section{JURNAL ABDIMAS

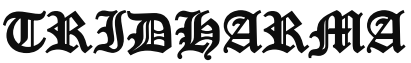

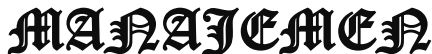

P-ISSN 2615-6849, E-ISSN 2716-070X

Jurnal ABDIMAS Vol. 1,No.2, Mei 2020,Hal(25-32)

@Prodi Manajemen Fakultas Ekonomi Universitas Pamulang

Email: abdimasjurnal.unpam@gmail.com Telp: (021) 741-2566

before the community service activities are carried out first, the socialization stage is to make a friendship with the chairman of the foundation, conveying the aims and objectives of this service. At this stage also carried out the fabric of cooperation and determine the schedule of service activities. The implementing team of community service activities is 5 people from the Faculty of Economics majoring in management. The dedication team provides material on financial management and financial management.

The conclusion of this dedication is that Participants are given material on financial management which is administrative in nature related to the activities of budget planning, storage, use, recording and supervision of the entry and exit of money / funds, groups of women in the village of West Pamulang.

Keywords: Family Finance, Family Income, and Family Expenditures

\section{PENDAHULUAN}

Analisis situasi warga kelurahan Pamulang Barat berada di kecamatan pamulang kota tangerang selatan provinsi banten. Di Pamulang barat terdapat beberapa komplek perumahan seperti Witana Harja Country Estate, Sinar Pamulang Permai, Reni Jaya, Vila Pamulang, Griya Jakarta, Vila Pamulang Mas, Pamulang Estate (MA), BPI (Bukit Pamulang Indah), Permata Pamulang, Vila Dago dll. Komplek-komplek perumahan ini mulai berdiri tahun 1983 .

Manusia, finansial, modal fisik dan teknologi adalah jenis-jenis sumber daya organisasi unit bisnis yang perlu dikelola dengan optimal untuk mencapai tujuan organisasi. Manajemen pada dasarnya merupakan proses pemanfaatan sejumlah sumber daya organisasi untuk mencapai tujuan tertentu melalui proses perencanaan, pengorganisasian, pengarahan dan pengendalian. Bagi seorang manusia, memiliki keluarga adalah sangat penting dala $\mathrm{m}$ hidup. Kebahagiaan keluarga akan membawa kebahagiaan bagi diri manusia.

Bagi seorang wirausaha, apapun yang dilakukannya adalah bagian dari upaya untuk membah agiakan keluarga. Dalam mengelola manajemen keluarga, yang bertindak sebagai manajer biasanya adalah ibu rumah tangga. Ada dua konsep utama tentang manajemen keuangan keluarga yang wajib diketahui oleh warga pamulang barat yaitu tentang Neraca dan Rugi/Laba serta Manajemen Cashflow/Arus Kas, Cashflow atau arus kas adalah aliran uang yang mengalir mulai dari kita mendapatkan uang tersebut, menyimpannya, mengembangkannya, dan mengeluarkannya dengan secara teratur, bijak dan disiplin. Ada pun alur cashflow yaitu:

$$
\text { a. Pendapatan (income) }
$$
adalah kegiatan yang bertujuan memasukkan uang/harta. Biasanya pendapatan dapat diperoleh dari dua aktivitas, yaitu Gaji dan Investasi.

b. Pengeluaran berarti seluruh kegiatan yang mengakibatkan uang berkurang.

c. Catatan atas Laporan Kekayaan adalah sebuah laporan yang menyajikan posisi atau kondisi daftar harta dan utang keluarga pada periode tertentu.

Dengan demikian, melihat berbagai permasalahan mendasar tersebutlah, Tim PKM dari Unpam hadir dalam memberikan pemahaman terkait manajemen keuangan dan pengelolaan keuangan keluarga. Dengan harapan dapat di implementasikan dalam keseharian kelompok Ibu-Ibu pengajian se-kelurahan Pamulang Barat. Kegiatan PKM ini bertema "Pengelolaan Keuangan Keluarga Pada Kelompok Pengajian IbuIbu Sekelurahan Pamulang Barat, Tangerang Selatan." 


\section{JURNAL ABDIMAS

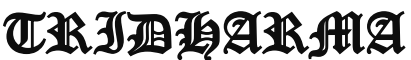

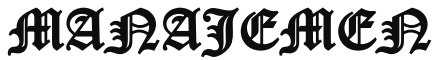

P-ISSN 2615-6849, E-ISSN 2716-070X

Jurnal ABDIMAS Vol. 1,No.2, Mei 2020,Hal(25-32)

@Prodi Manajemen Fakultas Ekonomi Universitas Pamulang

Email: abdimasjurnal.unpam@gmail.com Telp: (021) 741-2566

\section{RUMUSAN MASALAH}

Melihat dari permasalahan diatas, maka adapun rumusan masalah dalam kegiatan PKM ini adala sebagai berikut:

a.Bagaimana Manajemen Keuangan pada Kelompok Pengajian Ibu-Ibu Sekelurahan Pamulang Barat?

b.Bagaimana Pengelolaan keuangan keluarga pada Kelompok Pengajian IbuIbu Sekelurahan Pamulang Barat?

c.Apa yang harus dilakukan oleh Kelompok Pengajian Ibu-Ibu Sekelurahan Pamulang Barat, jika mau menerapkan pengelolaan keuangan keluarga yang konsisten?

\section{TUJUAN PELAKSANAAN}

Adapun tujuan dari PKM ini adalah sebagai berikut:

a.Untuk Mengetahui Manajemen Keuangan pada Kelompok Pengajian IbuIbu Sekelurahan Pamulang Barat.

b.Untuk Mengetahui Pengelolaan keuangan keluarga pada Kelompok Pengajian Ibu-Ibu Sekelurahan Pamulang Barat.

c.Untuk Mengetahui yang harus dilakukan oleh Kelompok Pengajian Ibu-Ibu Sekelurahan Pamulang Barat, jika mau menerapkan pengelolaan keuangan keluarga dalam Rumah Tangga.

\section{TINJAUAN PUSTAKA}

Manajemen adalah sebuah proses untuk mengatur sesuatu yang dilakukan oleh sekelompok orang atau organisasi untuk mencapai tujuan organisasi tersebut dengan cara bekerja sama memanfaatkan sumber daya yang dimiliki.

Secara etimologi kata manajemen diambil dari bahasa Perancis kuno, yaitu menagement, yang artinya adalah seni dalam mengatur dan melaksanakan. Manajemen dapat juga didefinisikan sebagai upaya perencanaan, pengkoordinasian, pengorganisasian dan pengontrolan sumber daya untuk mencapai sasaran secara efisien dan efektif.

Efektif dalam hal ini adalah untuk mencapai tujuan sesuai perencanaan dan efisien untuk melaksanakan pekerjaan dengan benar dan teroganisir.

Menurut T. Hani Handoko, ada tiga alasan utama mengapa manajemen diperlukan:

a. Manajemen diperlukan agar tujuan pribadi dan organisasi dapat tercapai

b. Berikutnya, manajemen juga diperlukan untuk menjaga keseimbangan antara tujuan-tujuan, sasaran, dan kegiatan, yang saling bertentangan dari pihak yang punya kepentingan dalam organisasi.

c. Manajemen dibutuhkan untuk mencapai efisiensi dan efektivitas suatu kerja organisasi

Manajemen keuangan merupakan segala kegiatan ataupun aktivitas pada perusahaan yang berhubungan dengan bagaimanakah caranya agar bisa mendapatkan pendanaan modal kerka, menggunakan atau mengalokasikan dana tersebut serta mengelola asset yang telah dimiliki perusahaan guna mencapai tujuan utama pada suatu perusahaan.

Menurut pendapat yang lainnya, definisi dari manajemen keuangan dapat di artikan sebagai suatu manajemen dana baik itu yang berhubungan dengan permasalahan pengalokasian dana dalam berbagai bentuk investasi secara efektif maupun usaha pengumpulan dana dalam pembiayaan investasi maupun pembelanjaan secara efisien.

Meskipun fungsi dari seorang manajer keuangan pada tiap perusahaan belum tentu sama tetapi prinsip utama seorang manajer keuangan pasti sama yaitu merencanakan, mencari serta memanfaatkan dengan berbagai cara guna memaksimalkan daya guna dari operasioperasi perusahaan. 


\section{JURNAL ABDIMAS

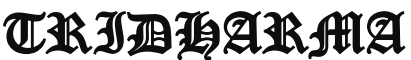

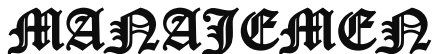

P-ISSN 2615-6849, E-ISSN 2716-070X

Jurnal ABDIMAS Vol. 1,No.2, Mei 2020,Hal(25-32)

@ Prodi Manajemen Fakultas Ekonomi Universitas Pamulang

Email: abdimasjurnal.unpam@ gmail.com Telp: (021) 741-2566

\section{Tujuan Manajemen Keuangan}

Tujuan dari manajemen keuangan telah terlihat dalam proses penilaian yang dilakukan oleh pasar uang, tujuan utamanya yaitu memaksimalkan kekayaan pemegang saham. Menurut para ahli, tujuan manajemen keuangan yaitu untuk:

1.Memaksimalkan keuntungan: seorang manajer keuangan tidak menjamin keuntungan dalam jangka waktu yang panjang sebab ketidakpastian bisnis tetapi perusahaan bisa mendapatkan keuntungan yang maksimal bahkan dalam jangka waktu yang panjang apabila manajer keuangannya mengambil suatu keputusan keuangan yang tepat serta menggunakan keuangan perusahaan dengan baik.

2.Menjaga arus kas (cash flow): suatu perusahaan harus mempunyai arus kas yang sesuai guna membayar biaya kebutuhan perusahaan sehari-hari seperti pembelian bahan baki, pembayaran gaji karyawan, sewa, dan sebagainya. Arus kas atau cash flow yang baik tentunya akan meningkatkan keberhasilan perusahaan

3.Mempersiapkan struktur modal: seorang manajer keuangan harus dapat memutuskan rasio antara pembiayaan yang dimiliki dan keuangan yang dipinjam agar dapat seimbang.

4.Pemanfaatan keuangan yang tepat: manajer keuangan harus bisa memanfaatkan keuangan secara optimal dan perusahaan harus tidak berinvestasi keuangan perusahaan dalam proyek yang tidak menguntungkan bagi perusahaan.

5.Memaksimalkan kekayaan: jadi seorang manajer keuangan mencoba agar agar memberikan dividen yang maksimal kepada pemegang saham dan berupaya dalam meningkatkan nilai pasar saham sebab nilai pasar saham secara langsung berkaitan dengan kinerja perusahaan

6.Meningkatkan efisiensi: manajemen keuangan mencoba meningkatkan efisiensi semua departemen perusahaan. Distribusi keuangan yang tepat dalam semua aspek akan meningkatkan efisiensi seluruh perusahaan

7.Kelangsungan hidup perusahaan: perusahaan harus dapat bertahan hidup pada dunia bisnis yang kompetitif seperti sekarang ini. Seorang manajer keuangan harus berhati-hati saat membuat keputusan keuangan sebab apabila salah dalam mengambil keputusan bisa saja perusahaan bangkrut atau merugi

8.Mengurangi resiko operasional: manajemen keuangan juga mencoba dalam mengurangi resiko operasional. Terdapat banyak resiko ketidakpastian dalam bisnis namun seorang manajer keuangan harus bisam mengambil langkah tepat agar dapat mengurangi resiko ini.

9.Mengurangi biaya modal: manajer keuangan harus dapat merencanakan struktur modal sedemikian rupa agar biaya modal dapat di minimalkan

Proses Pengelolaan Keuangan tidak seperti bendahara kelas yang terkesan tugasnya hanya menyimpan dan mengumpulkan uang, manajemen keuangan mempunyai polemik yang lebih kompleks mulai dari perencanaan hingga evaluasi. Setiap manajer harus membuat perencanaan keuangan instansi yang ia tangani. Perencanaan atau rancangan keuangan tersebut menggambarkan bayangan tentang proses perputaran uang di instansi tersebut dalam selang waktu tertentu, seperti berapa dana yang dibutuhkan sebagai modal awal, berapa uang yang akan ditetapkan sebagai biaya 


\section{JURNAL ABDIMAS

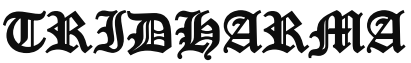

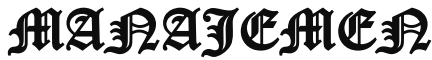

P-ISSN 2615-6849, E-ISSN 2716-070X

Jurnal ABDIMAS Vol. 1,No.2, Mei 2020,Hal(25-32)

@Prodi Manajemen Fakultas Ekonomi Universitas Pamulang

Email: abdimasjurnal.unpam@ gmail.com Telp: (021) 741-2566 bulanan dan berapa pula laba per-bulan, atau berapa dana yang dibutuhkan untuk memenuhi fasilitas pekerja dan kapan dana tersebut dapat diperoleh, diperlukan juga rancangan sumber dana.

Selain rencana keuangan diperlukan juga strategi dalam mengelola uang. Strategi diperlukan agar proses perputaran uang di instansi tersebut tidak berhenti dan mengantisipasi kemungkinan terburuk terjadi. Setelah persiapan sudah disiapkan dengan sangat matang masuklah masa dimana manajer melakukan tugas utamanya yakni me-manage pengelolaan keuangan instansi atau perusahaan tersebut.

Penggunaan uang harus dikontrol sebaik mungkin guna menghindari kemungkinan buruk terjadi di masa mendatang. Semua proses pengerjaan seorang manajer haruslah direkam, biasanya dilakukan dalam bentuk tulisan. Tulisan berisi laporan yang dalam selang waktu tertentu dilakukan evaluasi secara rutin mengenai regulasi uang di instansi tersebut. Dari evaluasi tersebut akan terlihat kinerja dari seorang manajer selama selang waktu terebut dan dari evaluasi tersebut juga akan terlihat kekurangan apa yang terjadi selama ini dan diharapkan tidak terulangi lagi di masa mendatang.

Evaluasi yang dilakukan dalam
selang waktu tertentu juga akan
memudahkan proses pembuatan laporan
pertanggungjawaban nantinya. Seorang
manajer keuangan harus membuat laporan
pertanggung jawaban untuk mempertanggung jawabkan atas apa yang selama ini ia kerjakan. Hal ini penting karena inilah salah satu faktor utama yang meningkatkan profesionalitas seorang manajer keuangan, trade record-nya akan bagus jika pekerjaan yang dilakukan bagus dan ia mampu bertanggung-jawab atas apa yang ia kerjakan.

Mengelola keuangan keluarga dengan baik merupakan salah satu kunci kesuksesan keluarga.Pengelolaan keuangan keluarga atau rumah tangga ini lebih rumit dibandingkan mengelola keuangan pribadi karena melibatkan banyak orang yaitu suami, istri dan anakanak.Jika pengelolaan keuangan rumah tangga ini berjalan benar, maka beruntunglah anggota keluarga.Namun kalau salah kelola, maka siap-siaplah mengalami masalah keuangan bahkan sebelum habis bulan. Siapapun yang bertanggungjawab mengelola keuangan keluarga, apakah istri atau suami, dia bertugas mengatur pengeluaran, mulai dari dana operasional hingga cicilan kartu kredit, uang sekolah anak, liburan, bantuan sosial atau agama, hingga jajan di luar rumah. 'Bendahara' keluarga ini didorong untuk lebih kreatif dan hati-hati dalam soal ini, karena keberlangsungan rumah tangga tergantung dari pintarnya mereka mengatur uang. Berikut tujuh jurus jitu hemat mengelola keuangan rumah tangga yang bisa ditiru (www.bisniskeuangan.kompas.com):

a. Tahu Detil Pemasukan dan Pengeluaran, Berapa pendapatan Anda dan pasangan tiap bulannya? Jumlahkan dengan benar. Setelah itu, hitung juga berapa pengeluaran rutin rumah tangga, seperti tagihan listrik, telepon, air, belanja bulanan dan tagihan lainnnya yang harus Anda keluarkan tiap bulannya. Jika Anda punya cicilan rumah, kendaraan atau kartu kredit, jangan lupa dihitung juga sebagai pengeluaran rutin. Dengan begitu, Anda akan mengetahui berapa kisaran pengeluaran rumah tangga tiap bulannya. Pastikan pengeluaran Anda tidak lebih besar dari pemasukan. Kalau iya, keuangan rumah tangga Anda dalam bahaya dan harus segera diatasi.

b. Pangkas Kebutuhan Tidak Penting. Buatlah catatan rutin berapa kebutuhan rumah tangga tiap bulannya, berapa dana yang akan disimpan atau diinvestasi dan rencana-rencana keuangan lainnya. Anda juga harus mengecek anggaran mana yang dibutuhkan, dan anggaran mana yang harusnya dipotong. Anda disarankan 


\section{JURNAL ABDIMAS

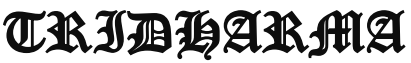

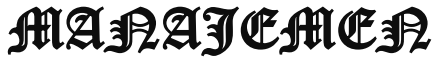

P-ISSN 2615-6849, E-ISSN 2716-070X

Jurnal ABDIMAS Vol. 1,No.2, Mei 2020,Hal(25-32)

@ Prodi Manajemen Fakultas Ekonomi Universitas Pamulang

Email: abdimasjurnal.unpam@ gmail.com Telp: (021) 741-2566 membuat rencana keuangan yang realistis dan masuk akal. Jangan sampai terlalu pelit atau terlalu hemat. Misalnya, anggaran jalan-jalan setiap dua kali selama sebulan, dipotong menjadi sekali dalam sebulan. Pemotongan anggaran ini bisa mengurangi waktu Anda bersenangsenang bersama anak dan pasangan Anda. Mungkin Anda bisa memilih tempat jalan-jalan yang lebih murah dari sebelumnya.

c. Jangan Tunda membayar Semua Kewajiban. Segeralah membayar kewajiban sebelum uangmu habis. Misalnya membayar uang sekolah anak, tagihan kartu kredit, cicilan mobil dan lain-lain. Bila semua kewajiban sudah diselesaikan, maka pengelolaan uang untuk operasional dan kebutuhan sehari-hari akan lebih mudah. Sebab kewajiban atau utang itu akan menimbulkan konsekuensi jika ditunda. Misalnya Anda akan menerima denda atau bunga sehingga kewajiban Anda bertambah besar.

d. Menabung dan Investasi. Pastikan selalu menyisihkan sejumlah uang untuk tabungan dan investasi. Tabungan bisa dijadikan dana darurat, sementara investasi bisa dijadikan tabungan masa depan. Lebih baik lagi kalau jumlah uang yang ditabung selalu konsisten setiap bulan, sehingga Anda punya ancer-ancer tersendiri. Untuk melakukan investasi, Anda punya banyak pilihan. Misalnya saja investasi emas, reksadana, saham, tanah, properti, hingga menabung di deposito.

e. Miliki Asuransi. Anda juga harus menyisihkan uang untuk membeli premi asuransi. Apalagi kalau kamu sudah memiliki tanggungan anak. Dengan asuransi maka setiap risiko akan diminimalisir dan dialihkan ke pihak asuransi. Jadi, apa pun yang terjadi, keuangan keluarga tidak akan gonjang ganjing.

f. Buat Daftar Belanja Bulanan. Pengeluaran terbanyak dalam rumah tangga adalah untuk berbelanja bahan pokok dan kebutuhan rumah. Sebelum berbelanja, pastikan Anda sudah memiliki daftar apa saja yang harus dibelanjakan sehingga menghindari Anda dari lapar mata. Anda juga bisa mengecek diskon yang diberikan swalayan sehingga belanja akan lebih hemat. Kalau Anda berbelanja dengan kartu kredit, pastikan kartu kreditmu cocok untuk berbelanja di swalayan, sehingga Anda mendapatkan keuntungan ekstra seperti cash-back dan lain-lain

g. Kurangi Kebiasaan Jajan. Jajan termasuk pengeluaran rumah tangga yang tidak terelakkan. Terutama bila keluarga doyan ngemil dan wisata kuliner. Tak heran pengeluaran yang satu ini berpengaruh pada kondisi tata kelola keuangan rumah tangga. Nah, tidak ada salahnya Anda dan keluarga mulai mengurangi kebiasaan jajan di luar rumah. Namun bukan berarti menghapus sama sekali anggaran tersebut. Cobalah melakukan penghematan, bukan menghapus anggaran. Anda bisa menggunakan promosi kartu kredit di restoran tertentu, selama masih sesuai dengan anggaran keluarga. Dengan kartu kredit Anda bisa mendapatkan diskon dan cash back, tapi bisa menikmati jajanan yang cukup mewah bersama keluarga.

\section{METODE PELAKSANAAN}

Metodepelaksanaan pengabdian ini dilakukan dalam beberapa kegiatan yaitu tahap survei yaitu sosialisasi dilakukan dengan menyusun berbagai hal yang akan disampaikan pada saat kegiatan pengabdian yang akan dilakukan yang meliputi: penyusunan materi yang akan diberikan, penyusunan jadwal pemberian materi, pembagian tugas tim pengabdian dan survei ke lokasi pengabdian. Tahap sosialisasi yaitu sebelum kegiatan pengabdian dilaksanakan terlebih dahulu dilakukan tahap sosialisasi yaitu melakukan silaturahmi dengan ketua 


\section{JURNAL ABDIMAS

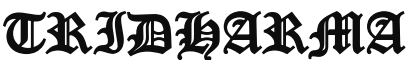

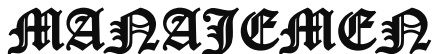

P-ISSN 2615-6849, E-ISSN 2716-070X

Jurnal ABDIMAS Vol. 1,No.2, Mei 2020,Hal(25-32)

@ Prodi Manajemen Fakultas Ekonomi Universitas Pamulang

Email: abdimasjurnal.unpam@gmail.com Telp: (021) 741-2566 yayasan, menyampaikan maksud dan tujuan pengabdian ini. Pada tahap ini juga dilakukan jalinan kerjasama dan menentukan jadwal kegiatan pengabdian. Tim pelaksana kegiatan pengabdian pada masyarakat adalah dosen Fakultas Ekonomi jurusan manajemen sebanyak 5 orang. Tim pengabdian memberikan materi tentang Pengelolaan keuangan keluarga pada Ibu-ibu pengajian sekelurahan Pamulang Barat, Tangerang Selatan..

\section{HASIL DAN PEMBAHASAN}

Pengabdian Masyarakat (LPPM) Universitas Pamulang yang dilakukan oleh dosen-dosen program studi Manajemen telah berjalan dengan lancar dan mendapat sambutan hangat dari tempat pelaksanaan kegiatan ini yaitu di Kelurahan Pamulang Barat,Tangerang Selatan .

Beberapa ibu-ibu rumah tangga sebagian besar belum menerapkan pengelolaan keuangan dengan baik, hal ini terjadi disebabkan berbagai faktor, diantaranya sebagai berikut: belum stabil,

a. Tingkat pendapatan yang

b. Faktor pendidikan,

c. Minimnya informasi tentang pengetahuan pengelolaan keuangan keluarga.

d. Belum adanya kesadaran untuk melakukan pengelolaan keuangan keluarga.

\section{KESIMPULAN DAN SARAN \\ Kesimpulan}

Manajemen keuangan dapat dilakukan sesuai dengan prosedur dan teori-teori yang akurat.Pengelolaan keuangan yang sifatnya administratif berkaitan dengan kegiatan perencanaan anggaran, penyimpanan, penggunaan, pencatatan dan pengawasan keluar masuknya uang/dana, kelompok Ibu-ibu pengajian sekelurahan Pamulang Barat

\section{Saran}

Meskipun pada saat ini kelompok Ibu-Ibu pengajian di sekelurahan
Pamulang Barat belum sepenuhnya melakukan pengelolaan keuangan secara administratif. Maka dengan ilmu-ilmu yang telah disampaikan dapat mulai dijalankan dengan baik dan benar; Untuk pengelolaan keuangan yang baik, kelompok ibu-ibu pengajian dapat konsisten dan komitmen dalam menjalankannya; dan Kelompok Ibu-ibu pengajian sekeleurahan Pamulang Barat dapat melakukan kegiatan tambahan, dengan berwirausaha.

\section{DAFTAR PUSTAKA}

Astutik. Endang Puji. 2019. Analisis Seberapa Jauh Tingkat Pendidikan Menentukan Baik Buruknya Pengelolaan Keuangan Keluarga Di Wilayah Jakarta Selatan,Pamulang: Jurnal Disrupsi

Qurbani, D., Oktrima, B., \& Tanjung, A. W. (2019). MENDIDIK DAN MENGAJARKAN ANAK UNTUK MENGENAL ALLAH PADA USIA DINI DENGAN METODE STORY TELLING DI TK AL-HIDAYAH PAMULANG, TANGERANG SELATAN. Jurnal Pengabdian Dharma Laksana, 1(2), 228-239.

Krisnaldy,,Gos Ishak (2018).

Manajemen wajtu dalam penggunaan gadget dan alat komunikasi era saat ini Jurnal Pengabdian Dharma Laksana, 1(2), 150-160.

Nurhidayah, Fitriyah. Irma Paramita Sofia, Sila Ninin Wisnantiasri, Putri Mutira . 2017. Pelatihan Pengelolaan Keuangan Keluarga bagi Ibu Rumah Tangga pada Kelompok Pemberdayaan dan Kesejahteraan Keluarga (PKK) di Kelurahan Sawah Baru Kecamatan Ciputat Tangerang Selatan Banten, Jakarta: Proceeding of Community Development. 


\section{JURNAL ABDIMAS

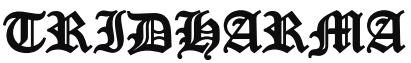

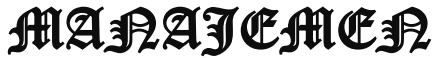

P-ISSN 2615-6849, E-ISSN 2716-070X

Jurnal ABDIMAS Vol. 1,No.2, Mei 2020,Hal(25-32)

@ Prodi Manajemen Fakultas Ekonomi Universitas Pamulang

Email: abdimasjurnal.unpam@gmail.com Telp: (021) 741-2566
Nurwita, N., Susanti, F., Permada, D. N. R., \& Oktrima, B. (2020). DAMPAK BURUK PEMAKAIAN MEDIA SOSIAL TERHADAP SEMANGAT DAN CAPAIAN BELAJAR SISWA SMP ARRAISIYAH PAMULANG". Jurnal ABDIMAS, 1(1).

Pasaribu, V. L. D., Agrasadya, A., Shabrina, N., \& Krisnaldy, K. (2020). MENJADI ENTERPRENEUR MUDA YANG MEMILIKI JIWA LEADERSHIP UNTUK MENGHADAPI MASA DEPAN. Abdi Laksana, 1(1).

Pasaribu, V. L. D., Elburdah, R. P., Sudarso, E., \& Fauziah, G. (2020). PENGGUNAAN MANAJEMEN WAKTU TERHADAP PENINGKATAN PRESTASI BELAJAR DI SMP ARAISIYAH. Jurnal ABDIMAS, 1(1). Pasaribu, V. L. D., Susanti, F., \& Hartuti, E. T. K. (2019). MEMOTIVASI SISWA DAN SISWI SMK LETRIS INDONESIA DI DALAM MENENTUKAN PILIHAN UNTUK MELANJUTKAN PENDIDIKAN ATAU BEKERJA SETELAH LULUS SEKOLAH. Jurnal Pengabdian Dharma Laksana, 1(2), 161-172.

\section{DOKUMENTASI FOTOKEGIATAN}

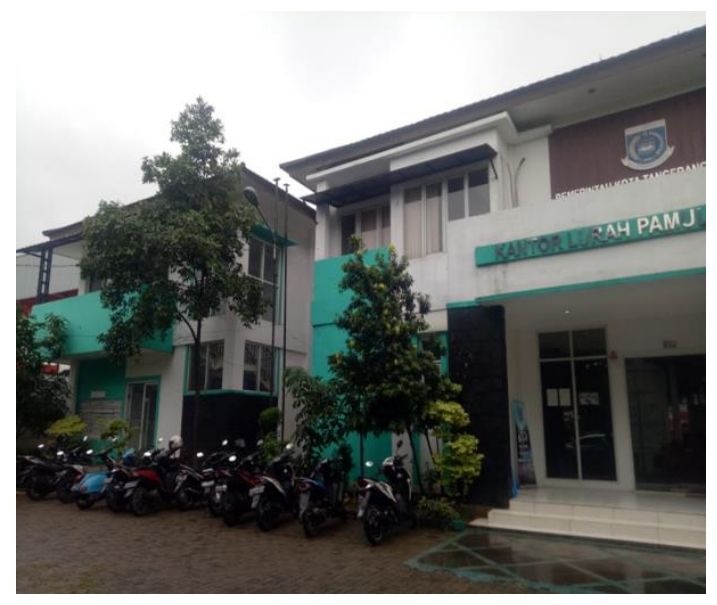

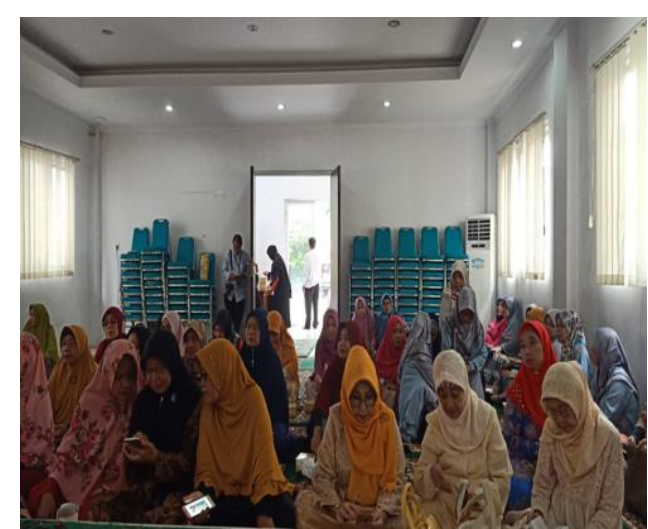
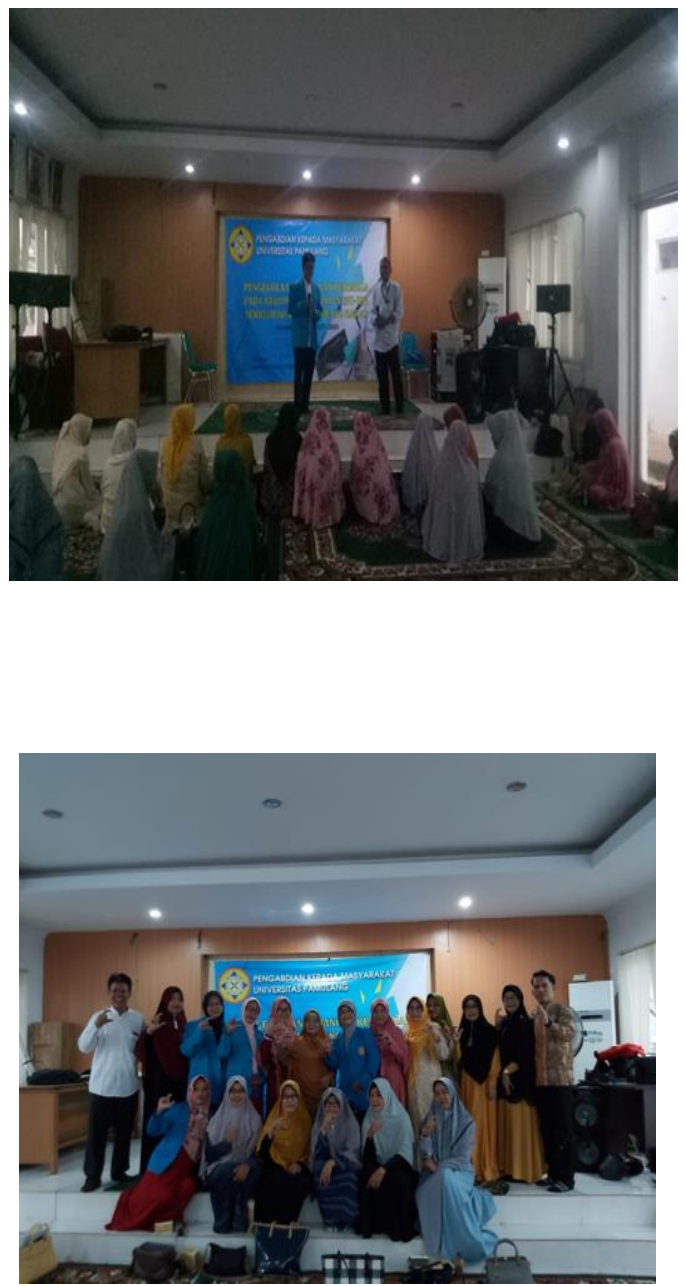